\title{
Facebook and Propaganda: Following Politics on Facebook and its Impact on Political Behaviors of Youth
}

\author{
M. T. Gondal (Maryam Tahira Gondal)', A. Munir (Asad Munir)'1, G. Shabir \\ (Ghulam Shabir)², A. Naz (Arab Naz) $^{3}$
}

1 PhD Scholar, Media Studies Department, The Islamia University of Bahawalpur, Pakistan.

2 Department of Media Studies, The Islamia University of Bahawalpur, Pakistan.

${ }^{3}$ Faculty of Social Science \& Chairman Sociology University of Malakand, Pakistan.

\section{E-mail address:}

arab_naz@yahoo.com

\section{Reprint address:}

Arab Naz

Department of Sociology

University of Malakand

Khyber Pakhtunkhwa

Pakistan

Source: Clinical Social Work and Health Intervention

Pages: $27-33$
Volume: 10

Issue: 3

\section{Reviewers:}

Jirina Kafkova

Nairobi, St. Bakitha Clinic, KE

Zofia Szarota

Pedagogical University of Cracow, PL

\section{Keywords:}

Cyber Crime. Facebook Content. Political Communication. Propaganda. Defamation Background of the Study.

\section{Publisher:}

International Society of Applied Preventive Medicine i-gap

CSWHI 2019; 10(2): 27 - 33; 10.22359/cswhi_10_3_04 @ 2019 Clinical Social Work and Health Intervention

\section{Abstract:}

Facebook is an application used globally, and is probably the most utilized application for political discussions. In developing countries like 
Pakistan whereby literacy and education levels are so low such social media are often misused. In most instances, people are unaware of the ethical usage of such applications. Framed under qualitative research design, this study aims to describe Facebook as a tool for political propaganda and vested political interests. A total of 400 samples (200 from Punjab and 200 from Sindh) were selected through stratified random sampling. A five level questionnaire was designed relevant to the objectives and research questions of the study whereas the information has been analyzed quantitatively including descriptive and inferential statistics. Findings show that young people in Punjab, Pakistan are greatly exposed to political contents on Facebook which affects their political behaviors.

Facebook was made non-exclusive to the world in Sept, 2006. Since then, it has evolved into something far more universal than its competitors. It is surely not the only social medium tapping in on an inexhaustible pool of chatty, enthusiastic, largely young user base. Rather it is the social media giant. For now, Facebook remains a go-to place for modern users of social media and its success is unsurpassed. Many physical gestures and face to face communications have been replaced by likes, messages, comments and friend requests. This digital age has sped up our communication and opened up a world of infinite choices. Usage of social media and Facebook and translation of online participation into political actions and voting trends was studied in the 2008 US election and it was found that people who participated in political debates and expressed political affiliation online were likely to participate in real life activities, etc. (The Express Tribune, 2013).

\section{Usage of social media by politicians}

A cross-sectional study where 88 students of college level were researched showed that Facebook and Twitter accounts managed by politicians affected the voting intentions of the sampled students. The accounts were managed by politicians in order to convey their political messages including contents such as speeches, political gatherings information, photos of political activities, etc. Following these accounts were found to be significant in molding the voting behaviors of the sampled students (Hellweg, 2011). A study conducted in Romania concluded that during elections politicians utilized social media in order to convey their political messages which altered and guided young minds in many ways. The social media worked in positive as well as negative ways. However, exploitations of political emotions was the most note-able one (Lupascu, 2012). Propaganda conveyed through Facebook is almost always directed to use good words for wrong purposes particular when used by politicians. A meta-analysis indicated that good words were projected in a manner that meant presenting opposing people negatively. It was also evident that the majority of sampled individuals were unaware of the use of such words for presenting others negatively and were influenced by the good words while not considering the negative impact of the words about the opposing people (ŞUTIU, 2015).

In the modern era it is a fact that social media including Facebook has played a significant role in many political scenarios. For instance, in Ukraine, Facebook and Twitter brought revolution. Similarly, the political situations in Egypt and certain Arab countries 
are directed by Facebook and Twitter. Besides, Facebook was a source of communicating war scenes from Afghanistan to the global community by American soldiers (Ibrahim, 2015). Another key dimension of social media usage by politicians is its mediation through intelligence. The conflicts are old but the mechanisms of mediating people is new in nature through Facebook. Globally, politicians are active in using social media to activate their followers against their opposition by sharing information regarding them and sensitizing their followers by highlighting the time to take action and even the places to take actions (Treverton \& Miles, 2014).

\section{Study Argument}

Social media is a powerful tool in the modern world. It is utilized in each and every sphere of life including education, health, business, entertainment, communication and similarly politics as well. Political parties, leaders and political workers utilize social media in order to convey their messages, information, news and political debates to the public whereas the public follows political parties, leaders and gets political news and information through social media particular Facebook and Twitter. The utilization and usage of social media for the mentioned political purposes have positive as well as negative implications. Among the negative implications, one is propaganda. For example, politicians cleverly play with minds of people to mold their attitudes and opinions about others through such an easy means. With regard to Pakistan the trend by politicians of utilizing social media has emerged. More and more political parties and leaders are communicating with the public through social media especially Facebook. The political attitudes of young people are significantly affected by the politicians through propagandas which are carried out by targeting others through words, symbols, pictures, memes and character assassination (Statista, 2015).

\section{Objectives Of The Study}

To create a profile of young users of Facebook following political parties and leaders

To investigate into the role of political propagandist in playing with young minds

To observe the role of Facebook in changing political attitudes of young users

\section{Research Questions}

What is the extent of consumption of political content on Facebook by university students at different levels?

What is the extent of attitudinal change caused by exposure to political propaganda campaigns on Facebook?

What is the extent of change in political behavior lead by the consumption of political contents on Facebook?

\section{Hypotheses}

$\mathrm{H}_{1}$ : More the reliance on Facebook for political information, more the political opinion will be influenced.

$\mathrm{H} 0$ : There is no relation between the consumption of political acebook content and attitudinal change.

\section{Research Methodology}

Survey design was adopted for the study and a questionnaire was the major tool developed on Likert Scale.

\section{Sampling Technique}

Randomization technique was used to collect data from a sample frame of 400 students in equal number of male and female, graduate and under graduate students of two randomly selected universities from Punjab and Sindh Provinces of Pakistan.

The following chart explains sampling technique: 




\section{Questionnaire Construction}

The questionnaire was designed in accordance to the mental depth and verbal capacity of the selected population. English was chosen to be the language of communication.

\section{Data Analysis}

\section{Descriptive Information}

In terms of targeting character of opposing leaders through social media 53\% respondents replied with to some extent while $44 \%$ to greater extent; $22 \%$ and $76 \%$ respondents replied with to some extent and to greater extent with that political parties and leaders' talks about policies of opposing parties and leaders through social media. However, 55\% of respondents marked to not at all against the statement that political leaders post jokes

Table 1: Elements of Political Propaganda by Political Parties and Leaders

\begin{tabular}{|l|c|c|c|}
\hline Statements & $\begin{array}{c}\text { Not at } \\
\text { all }\end{array}$ & $\begin{array}{c}\text { To some } \\
\text { extent }\end{array}$ & $\begin{array}{c}\text { To greater } \\
\text { extent }\end{array}$ \\
\hline $\begin{array}{l}\text { Political parties and leaders targets character(s) } \\
\text { of opposing parties and leaders }\end{array}$ & $3 \%$ & $53 \%$ & $44 \%$ \\
\hline $\begin{array}{l}\text { Political parties and leaders talks about policies } \\
\text { of opposing parties and leaders }\end{array}$ & $2 \%$ & $22 \%$ & $76 \%$ \\
\hline Political leaders post jokes about opposing leaders & $55 \%$ & $42 \%$ & $3 \%$ \\
\hline $\begin{array}{l}\text { Political parties and leaders post memes of opposing } \\
\text { leaders and parties }\end{array}$ & $75 \%$ & $21 \%$ & $4 \%$ \\
\hline $\begin{array}{l}\text { Political leaders exaggerates the wrong doings } \\
\text { of the opposing leaders }\end{array}$ & $7 \%$ & $66 \%$ & $27 \%$ \\
\hline $\begin{array}{l}\text { Politicians discuss over the personal issues of } \\
\text { opposing leaders }\end{array}$ & $63 \%$ & $25 \%$ & $12 \%$ \\
\hline
\end{tabular}


about opposing leaders; whereas $42 \%$ marked to some extent. Similarly, a majority i.e. $75 \%$ of respondents opted for not at all against the statement that political parties and leaders post memes of opposing leaders and parties while $21 \%$ respondents replied with to some extent. Further, $66 \%$ and $27 \%$ of respondents respectively stated that political leaders exaggerate the wrong doings of the opposing leaders. Lastly, $63 \%$ of respondents marked not at all against the statement that politicians discuss over the personal issues of opposing leaders while $25 \%$ and $12 \%$ replied with to some extent and to greater extent.

\section{Inferential Statistics}

\section{Regression Analysis}

Table 2: Model Summary ${ }^{\text {b }}$
Predictors: (Constant), Extent of reliance on Facebook for political information, How much Facebook is used

While testing the hypotheses through linear regression analysis, the value of $\mathrm{R}$ is found to be 0.763 and $\mathrm{R}$ square is 0.581 that is fairly closer to +1 indicating a positive correlation between independent and dependent variables. Significance level of $95 \%$ is achieved in the ANOVA Test. Value of Beta is 0.763 (closer to +1 instead of -1 ) and 0.000 (significant) that also indicates that the independent variables are creating causal effect on the dependent variable. Hence the 95\% confidence level is achieved to accept the alternate hypotheses and reject the null hypotheses and the results can be generalized to the whole population. There is a positive correlation between the

\begin{tabular}{|c|c|c|c|c|}
\hline Model & $\mathrm{R}$ & $\mathrm{R}$ Square & $\begin{array}{l}\text { Adjusted } \\
\text { R Square }\end{array}$ & $\begin{array}{c}\text { Std. Error of } \\
\text { the Estimate }\end{array}$ \\
\hline 1 & $.763^{\mathrm{a}}$ & .582 & .581 & .659 \\
\hline
\end{tabular}

Predictors: (Constant), Extent of reliance on Facebook for political information

Dependent Variable: Extent of change caused in previous political attitudes by political contents on Facebook extent of exposure to political posts on Facebook and change in political attitudes. There is also a positive correlation between reliance on Facebook political contents and change in political attitudes.

Table 3: ANOVAa

\begin{tabular}{|c|c|c|c|c|c|c|}
\hline \multicolumn{1}{|c|}{ Model } & $\begin{array}{c}\text { Sum of } \\
\text { Squares }\end{array}$ & Df & $\begin{array}{c}\text { Mean } \\
\text { Square }\end{array}$ & F & Sig. \\
\hline \multirow{3}{*}{$1 \quad$ Regression } & 481.289 & 2 & 240.644 & 553.946 & $.000^{\mathrm{b}}$ \\
& Residual & 346.231 & 797 & .434 & & \\
& Total & 827.520 & 799 & & & \\
\hline
\end{tabular}

Dependent Variable: Extent of change caused in previous political attitudes by political contents on Facebook 
Table 4: Coefficientsa

\begin{tabular}{|c|c|c|c|c|c|}
\hline & \multirow[t]{2}{*}{ Model } & \multicolumn{2}{|c|}{$\begin{array}{l}\text { Unstandardized } \\
\text { Coefficients }\end{array}$} & \multirow{2}{*}{$\begin{array}{c}\text { Standardi- } \\
\text { zed Coeffi- } \\
\text { cients }\end{array}$} & \multirow[t]{2}{*}{$\mathrm{T}$} \\
\hline & & B & Std. Error & & \\
\hline \multirow[t]{3}{*}{1} & (Constant) & .639 & .061 & & 10.403 \\
\hline & $\begin{array}{l}\text { How much Facebook is con- } \\
\text { sumed }\end{array}$ & .768 & .025 & .763 & 31.108 \\
\hline & $\begin{array}{l}\text { Extent of reliance on Facebook } \\
\text { for political information }\end{array}$ & .000 & .020 & .000 & .011 \\
\hline
\end{tabular}

\section{Discussion}

Facebook is one of the dominant social media services used around the world. Political parties and leaders use it to communicate with the public and their followers and thereby is a means of political propaganda. This study shows that political leaders and parties target the characters of opposing leaders and parties, post jokes and memes about opposing leaders and parties, and exaggerate the wrong doings of opposing parties, etc.

There is an evidence that young people in Punjab, Pakistan follow political parties and leaders through Facebook, and greatly depend on political information through Facebook. This is because they are greatly exposed to political contents on Facebook. Besides, the inferential statistics also show that exposure and reliance of information through Facebook molds and alters the political behavior and attitudes of young people in Punjab, Pakistan. These findings are in line with the studies of Dagona, Karick, \& Abubakar (2013), Ibrahim (2015), Smith (2011), Suiti (2015), Hellweg (2011) and the The Express Tribune (2013).

\section{Conclusion}

This study investigates the role of Facebook in spreading political propaganda and affecting political behavior of young people. The study has been conducted in Punjab, Pakistan. Randomize sampling technique has been utilized and data has been analyzed statistically including description and inferential statistics.

This study concludes that there are various elements of political propaganda on Facebook including posting memes and jokes against opposing parties and leaders; exaggerating there wrong doings; character assignation of opposition; etc. It is evident that young people in Punjab, Pakistan are greatly exposed to political contents on Facebook which affects their political behaviors.

\section{References:}

1. STATISTA (2015) Number of monthly active Facebook users worldwide as of 4th quarter 2015 (in millions). Retrieved January 06, 2016, from Statista: www.statista. com/statistics/264810/number-of-monthly-active-facebook-users-worldwide/.

2. THE EXPRESS TRIBUNE (2013, May 21) Pakistan election 2013 total voter turn out: 55\%. Retrieved December 28, 2015, from The Express Tribune.

3. HELLWEG A (2011) Social Media Sites of Politicians Influence Their Perception by Constituents. The Elon Journal of Undergraduate Research in Communications $\mathrm{p}$. 22-36.

4. LUPASCU N (2012) Electoral Campaigns in the Process of Transition to Democracy in Romania after December 1989. Research 
Theme: Local Campaign for Mayor's Office ofIasi, 2004 - The Construction of a Political Product. Romanian Journal for Multidimensional Education .

5. ŞUTIU C L (2015) Propaganda: How A Good Word Went Wrong. Agathos: An International Review of the Humanities and Social Sciences.

6. SILJANOVSKA L (2014) Mass Media And Cultural Memory: Idealization Of Values. South East European University, Tetovo, Macedonia, p. 113-122.

7. IBRAHIM A (2015) Communication between Communities in a Modern War Paradigm. SEA-Practical Application of Science, p. 259-261.

8. TREVE SMITH K N (2011) Social Media and Political Campaigns. University of Tennessee Honors Thesis Projects, p. 1-30.

9. JOSEPH S (2012) Social Media, Political Change and Human Rights. Boston College International and Comparative Law Review, p. $145-188$.
10. HARSIJ H, EBRAHIMIPOUR H, RAHBARQAZI M, MALEKAN M (2014) $A$ study of the relationship between cyberspace and political participation (The case study of students at the Univresity of Isfahan). Journal of Applied Sociology, p. 4346.

11. KUSHIN M J, YAMAMOTO M (2010) Did social media really matter? College students' use of online media and political decision making in 2008 election. Mass Communication and Society, p. 608-630.

12. KONARD (2010) Online Social Networking and Political Communication in Asia. (P. Behnke, Ed.) Singapore: Konard-Adenauer-Stiftung.

13. DAGONA Z, KARICK H, ABUBAKAR F (2013) Youth Participation in Social Media and Political Attitudes in Nigeria. Journal of Sociology, Psychology and Anthropology in Practice, $\mathrm{p}$ 1-7. 